Based Med. 2018 Oct;23:165-8.

2. Cochrane. About us. Date unknown [cited 2019 May 28]. Available from: https://www.cochrane.org/about-us

3. Lundh A, Lexchin J, Mintzes B, Schroll JB, Bero L. Industry sponsorship and research outcome. Cochrane Database Syst Rev. 2017 Feb 16: 2 MR000033. DOI: 10.1002/14651858.MR000033.pub3.

4. Ioannidis JPA. Cochrane crisis: Secrecy, intolerance and evidence based values. Eur J Clin Invest. 2018;e13058.doi:10.1111/eci.13058

5. Jefferson TO, Demicheli V, Di Pietrantoni C, Jones M, Rivetti D. Neuraminidase inhibitors for preventing and treating influenza in healthy adults. Cochrane Database Syst Rev. 2006 Jul 19;3:CD001265.

6. Doshi P. Neuraminidase inhibitors: the story behind the Cochrane review. BMJ. 2009 Dec 8;339:1348-51.

7. Kaiser L,Wat C, Mills T, Mahoney P,Ward P, Hayden F.Impact of oseltamivir treatment on influenza-related lower respiratory tract complications and hospitalizations. Arch Intern Med. 2003 Jul 28;163(4):1667-72.

8. Abbasi K. The missing data that cost \$20bn. BMJ. 2014 Apr 10;348:g2695

9. McCarthy M.What makes an essential medicine? WHO's new list focuses on antibiotic esistance, adds expensive drugs, and downgrades Tamiflu. BMJ. 2017 Jul 7; 358:j3044. doi:10.1136/bmj.j3044.

10. Jones M, Jefferson T, Doshi P, Del Mar C, Heneghan C, Onakpoya I. Commentary on Cochrane review of neuraminidase inhibitors for preventing and treating influenza in healthy adults and children. Clin Microbiol Infect. 2015 Mar; 21(3):217-21..
11. Jefferson T, Doshi P. Multi system failure: the story of anti-influenza drugs. BMJ.2014 Apr 9;348:g2263. doi:10.1136/bmj.g2263.

12. Jefferson $T$, Jones MA, Doshi $P$, Del Mar CB, Hama R, Thompson MJ, Spencer EA, Onakpoya IJ, Mahtani KR, Nunan D, Howick J, Heneghan CJ. Neuraminidase inhibitors for preventing and treating influenza in adults and children. Cochrane Database Syst Rev. 2014 Apr 10;4:CD008965. DOI: 10.1002/14651858.CD008965.pub4.

13. Kmietowicz Z. WHO downgrades oseltamivir on drugs list after reviewing evidence. BMJ. 2017 Jun 12;357:j2841 doi: 10.1136/bmj.j2841

14. Taylor F, Huffman MD, Macedo AF, Moore TH, Burke M, Davey Smith G, Ward K, Ebrahim S. Statins for the primary prevention of cardiovascular disease. Cochrane Database Syst Rev. 2013 Jan 31;1:CD004816.

15. Cholesterol Treatment Trialists' (CTT) Collaborators, Mihaylova B, Emberson J, Blackwell L, Keech A, Simes J, Barnes EH, Voysey M, Gray A, Collins R, Baigent $C$. The effects of lowering LDL cholesterol with statin therapy in people at low risk of vascular disease: meta-analysis of individual data from 27 randomised trials. Lancet. 2012 Aug 11;380(9841):581- 90.

16. Abramson JD, Rosenberg HG, Jewell N, Wright JM. Should people at low risk of cardiovascular disease take a statin? BMJ. 2013 Oct 22;347:f6123.

17. Parish E, Bloom T, Godlee F. Statins for people at low risk: Independent review of the trial data is an essential next step. BMJ.2015;351:h3908

18. Personal communication. May 20,2019.

\title{
Medical devices: Primum non nocere or Pecunia primum?
}

\section{RAYMOND DE VRIES}

\section{Jeanne Lenzer. The danger within us: America's untested, unregulated medical device industry and one man's battle to survive it. New York: Little Brown and Company; 2017.329 pages, US\$28.00. ISBN978-0- 316-34376-3.}

That medical device companies have an equal, if not stronger, interest in making money than they do in helping the sick and injured - than pecunia primum ("first make money") is more important that primum non nocere ("first do no harm")—will come as no surprise to most readers of this journal. Those who defend device companies might look at this fact and explain, "no money, no mission"- ie, the primary goal of the companies is, in fact, to help people, but if they fail to make a profit, they will be unable to achieve that goal. Others might point out that it is not as if the officers of medical device companies sit in smoke-filled rooms plotting to maximise profits, while shouting "the patient be damned." Rather it is a matter of "goal displacement" where proximate goals-

\footnotetext{
Author: Raymond De Vries (rdevries@umich.edu), CAPHRI School of Public Health/Academie Verloskunde Maastricht, Maastricht University, Maastricht, NETHERLANDS; Center for Bioethics and Social Sciences in Medicine, University of Michigan Medical School, Ann Arbor, Michigan, USA.

To cite: De Vries R. Medical devices: Primum non nocere or Pecunia primum? Indian J Med Ethics. 2019 Jul-Sep;4(3) NS:248-50. DOI:10.20529/JME.2019.038

Published online on July 18,2019.

Manuscript Editor: Sanjay A Pai.

OIndian Journal of Medical Ethics 2019
}

efficient production, making deadlines, meeting sales targetsbecome more important than the larger goal of helping those who may benefit from a medical device. No one person is responsible for the harm done to thousands by medical devices. The guilt is diffuse and shared by many, none of whom fully understands their contribution to the problem. Engineers design, managers manage, marketers market, lawyers defend, each simply doing what they are paid to do; none seeing their work as part of a conspiracy of harm.

In The danger within us: America's untested, unregulated medical device industry and one man's battle to survive it, Jeanne Lenzer describes the many ways people are injured, and even killed, by medical devices. More importantly, she carefully explains the elements that have (and continue to) come together to create a regulatory system that allows the well-being of patients to be ignored in favour of the interests of device companies. Lenzer's book joins several other book-length examinations of the harm caused by the "medical-industrial complex," including, among others, Shannon Brownlee's Overtreated (1), Barbara Ehrenriech's Natural causes (2), Marcia Angell's The truth about drug companies (3), Howard Brody's Hooked (4), and Peter Gotzsche's Deadly medicines and organized crime (5).

Irving Selikoff, a physician committed to public health, famously said, "Statistics are people with the tears wiped away." (6). Lenzer, an independent medical investigative journalist and regular contributor to the $B M J$, recognises the value of letting her readers go beyond statistics to see the tears of those who 
have suffered from the lack of oversight of the device industry. She weaves the history of the regulation of medical devices around the story of Dennis Fegan, a firefighter and paramedic who, as a result of unrelenting epileptic seizures, agreed to have a vagus nerve stimulator (VNS) implanted under his collar bone. The device stimulates the vagus nerve in an effort to reduce, if not stop, seizures. In the end, the device nearly killed Fegan, stopping his heart-in regular three-minute intervals. He survived, but the experience caused him to wonder how many others with an implanted VNS had suffered the same fate, and to question how such a device made it to the market. He sought the assistance of a number of medical journalists to aid in the quest, and Lenzer agreed.

The naïve reader will be surprised. Surely, the Food and Drug Administration, assigned the task of ensuring the safety and efficacy of medical devices in 1976, would prevent dangerous devices from entering the market. No. As Lenzer explains, the regulatory loopholes are large enough to drive a truck full of medical devices through. The approval process for Class 3 devices - those deemed "high risk," often implanted-involves the use of pre-market approval (PMA). This sounds reassuring until you learn about the $510(\mathrm{k})$ exemption - a feature that allows device makers to circumvent the approval process if their new device is "substantially equivalent" to a device that has already been approved. Lenzer cites a 2014 study from JAMA that found that "from 2008 through 2012, the FDA cleared for market approximately four hundred implanted medical devices considered of moderate to high risk-without requiring clinical testing" ( $p$ 121).

Why this slipshod oversight? Lenzer dissects the historical and political context that shaped current regulations. She identifies three factors that have come together to create the situation that Dennis Fegan and countless others have found themselves in (pp 57-8):

"the rise of technologically based medical care, the passage of Medicare, along with the rise of private health insurance, and the Bayh-Dole Act, which rewarded commercial research at universities [created] a behemoth made up of interlocking organizational interests: hospitals, insurers, professional medical associations, pharmaceuticals companies, device manufacturers, research institutions, medical journals, electronic-medical-record developers, and many more. All these parties are economically dependent, ultimately, on the existence of end products for sale: medical treatments, drugs, surgeries, and devices, from insulin to pacemakers to life support machines. Without those products, many of the insurers, the hospitals, the manufacturers, and even the doctors themselves, would have no market, no income and no reason for existing. Thus the logic of the marketplace makes it all but inevitable that this network of interested individuals and organizations must, consciously or unconsciously, devote much of its time, energy, and financial resources to promoting more sales of its products-more drugs, more medical procedures, more tests, mores surgeries, more medical devices..."
As a sociologist, I am driven to ask a further question: what are the cultural factors behind the creation of the structural and political incentives for minimal regulation of the device industry? There is something peculiarly American in our fascination with medical devices. We are a tinkering people think Henry Ford, the Wright brothers, Thomas Edison. We are fascinated by gadgets, looking for technological solutions to problems great and small, and, in this case, seeking salvation in medical gadgetry.

In an interview done with National Public Radio (US), Lenzer recognises our American fascination with technology:

"Everybody's tech-happy and thinks that the newest cutting-edge device must be better than the older device... when in fact that's not always the case...So newer isn't always better, and all the excitement about high-tech stuff needs to be moderated with an understanding that these things sometimes cause serious harms." (7)

When it comes to medical devices, we have an "irrational rationality." It seems only rational that newer is better, that machines can perform better than us fallible humans. When careful studies show that logic to be flawed, we become irrational, we hold on to our intuition that devices are better, even in the face of contrary evidence. This is nowhere more visible than in the use of cardiotocography (CTG, also referred to as electronic fetal monitoring) to monitor women in labour. We have known for decades that when compared to intermittent auscultation, CTG has no clinical benefit and, in fact, increases the likelihood of an unnecessary surgical birth (8). And yet the vast majority of women in labour are monitored with CTG. After all, how can the human ear be better than an electronic device?

This is an example of what Lenzer identifies as "cure as cause" (p 6). Murray Enkin, an obstetrician and healthcare researcher, gives a vivid illustration. Commenting on the oft-used analogy between an obstetrician and a fireman who rescues a baby from a burning house, Enkin notes, "the difference is that the fireman usually does not start the fire. We need firemen, but most houses are not on fire. If we treated every house as if it were on fire, we would do more damage than good."(9)

In that same interview with National Public Radio, Lenzer admits that she herself has an implanted medical device. She goes on, "I mean, lives are being saved and transformed in many positive ways. And that's part of what troubles me...I wouldn't have bothered with this if I didn't feel that there was some merit in the field. Medical devices can be wonderful. What we need is to be able to tell the difference between the ones that don't work and the ones that do work."(7) By exposing the many and complicated drivers of the current organisation of American health care, Lenzer's book is an important step toward helping us distinguish between helpful and harmful devices. Further reflection on our fascination with gadgets and with the "latest and newest" will help us take a more sober approach to regulating those devices, turning us away from pecunia primum and toward primum non nocere. 


\section{References}

1. Brownlee S. Overtreated: Why too much medicine is making us sicker and poorer. New York: Bloomsbury; 2008.

2. Ehrenreich B. Natural causes. Life, death and the illusion of control. New York: Granta Books; 2018.

3. Angell M. The truth about drug companies: How they deceive us and what to do about it. New York: Random House; 2005.

4. Brody H. Hooked: Ethics, the medical profession, and the pharmaceutical industry. New York: Rowman \& Littlefield Publishers; 2006.

5. Gotzsche P. Deadly medicines and organized crime: How Big Pharma has corrupted health care. New York: Routledge; 2013.
6. Selikoff, IJ. Statistical compassion. J Clin Epidemiol. 1991; 44(Suppl 1): 141S-146S.

7. Davies D. Are implanted medical devices creating a 'danger within us'? Npr.org. 2018 Jan 17 [cited 2019 Jun 20]. Available from https:// www.npr.org/2018/01/17/578562873/are-implanted-medical-devicescreating-a-danger-within-us

8. Spector-Bagdady K, De Vries R, Harris LH, Low LK. Stemming the Standard-of-Care Sprawl: Clinician Self-Interest and the Case of Electronic Fetal Monitoring. Hastings Center Report. 2017 Nov; 47(6):1624.

9. Personal communication to the author.

\section{Laakhon mein ek: for the greater common good}

\section{GANESH SINGH DHARMSHAKTU}

Laakhon mein ek, Season 2, Producer: Biswa Kalyan Rath, Director: Abhishek Sengupta, Hindi, 2019. 8 episodes. Amazon Prime Video.

Laakhon mein ek, Season 2, is an engaging drama series providing an authentic depiction of the rural posting of an upright young intern, Dr Shreya, at a primary health centre in a village called Sitlapur. The first season of this web series had followed the struggles of a young boy with artistic dreams forced to go to a coaching centre that prepares candidates for IIT entrance exams. The second season explores how $\mathrm{Dr}$ Shreya survives her rural tenure, made interesting as well as entertaining by a crisp script and commendable acting.

The show opens with a medical committee investigating a botched-up cataract surgical camp in a village. The committee is writing its final report and the story is played in flash-back The real-life challenges faced by doctors in primary health centres are portrayed unapologetically, and with realism. Forcible admission against the doctor's advice, violence at the workplace, siphoning off of hospital supplies and medicinesonly to make them available for cash-and the blind faith of the public in the local quack who prescribes all sorts of medication without any degree, are well known to doctors working at small centres.

The protagonist, Dr Shreya, superbly played by Shweta Tripathi, is given the task of organising a cataract camp in the village following the whim of the local politician hoping to gain political mileage in the coming elections. How she is compelled to organise the camp in a place where

Author: Ganesh Singh Dharmshaktu (drganeshortho@gmail.com), Associate Professor, Department of Orthopaedics, Government Medical College, Haldwani, Uttarakhand. 263139 INDIA

To cite: Dharmshaktu GS. Laakhon mein ek: for the greater common good. Indian J Med Ethics. 2019 Jul-Sep;4(3) NS:249. DOI: 10.20529/IJME.2019.050

Manuscript Editor: Sanjay A Pai

OIndian Journal of Medical Ethics 2019 basic facilities are lacking, funds scant, and infrastructure nonexistent, is the bitter reality and how the hard-pressed chief medical officer, support staff and fellow doctors try to help in achieving this task is vividly portrayed. The journey of a freshout-of-college intern completing a herculean task, amidst unsupportive colleagues and sceptical villagers, slowly winning them over, is heartening and may be educative for young doctors regarding the need for soft skills and empathy.

Social issues that need urgent solutions are explored in detail over the entire season like the angst of young doctors who do not wish to go to villages for want of basic amenities or due to the disturbance of their post-graduation preparation; the plight of CMOs having to beg or borrow to run the dispensaries; the nexus of local drug distributors and people with political clout making the most of tenders and contracts, siphoning off medicines, or in the worst scenario, disposing of expired drugs with new labels. All these bonafide problems demanding systemic reforms as well as a compassionate ear to the voices of care providers, are dealt with.

The reason why a respected family of the village has no faith in government healthcare services is traced sensitively to understand their despair regarding the system, which they fear will take more lives if they avail its services. This leaves them to depend on the local quack with little hope of a cure. Ultimately, the family confides in the doctor only to be cheated again by the system. The learning process is a harsh one for the protagonist, which makes the story more convincing.

The director has done a great job with well-researched content and a talented cast, avoiding unnecessary jargon and preaching. Intelligent viewers can derive their own meaning from the plot but the core message of ethics as the bedrock of good healthcare cannot be missed. The series suggests that while clinging to ethics is a tough job any day, selfless service together with ethical adherence is essential for the greater common good. 